$1-1-1924$

\title{
The Influence of Plot Size and Replication on Experimental Error in Field Trials with Potatoes
}

K. C. Westover

Follow this and additional works at: https://researchrepository.wvu.edu/ wv_agricultural_and_forestry_experiment_station_bulletins

\section{Digital Commons Citation}

Westover, K. C., "The Influence of Plot Size and Replication on Experimental Error in Field Trials with Potatoes" (1924). West Virginia Agricultural and Forestry Experiment Station Bulletins. 189.

https://researchrepository.wvu.edu/wv_agricultural_and_forestry_experiment_station_bulletins/189 @ WVU. It has been accepted for inclusion in West Virginia Agricultural and Forestry Experiment Station Bulletins by an authorized administrator of The Research Repository @ WVU. For more information, please contact ian.harmon@mail.wvu.edu. 


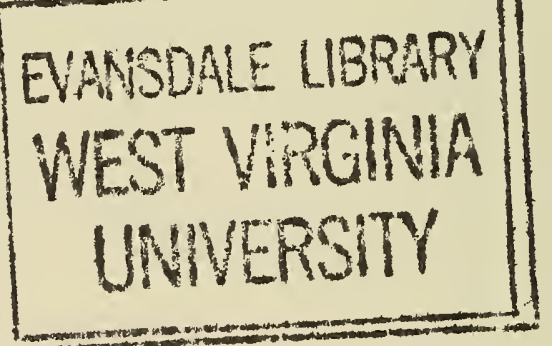




\section{Restricted}

\section{Circulation Only}


Digitized by the Internet Archive in 2010 with funding from

Lyrasis Members and Sloan Foundation 


\section{Aurtultural Fxperiment Station}

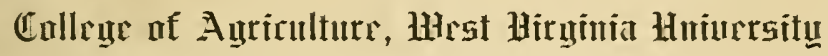

HENRY G. KNIGHT, Director

Morgantown

The Influence of Plot Size and Replication on Experimental Error in Field

\section{Trials with Potatoes}

(Technical)

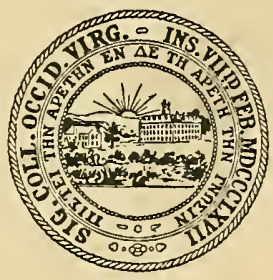

B Y

K. C. WESTOVER

Publications of this Station will be mailed free to any citizen of West Virginia upon written application. Address Director of the West Virginia Agrisultural Experiment Station, Morgantown $\mathrm{W}$. Va. 


\section{AGRICULTURAL EXPERIMENT STATION STAFF}

FRANK B. TROTTER, A. M., LI. D.

President of the University GEORGE R. LYMAN, Ph. D. Dean of the College of Agriculture HENRY G. KNIGHT, Ph. D.. Director of the Experiment Station C. E. STOCKDALE, B. S. Agr. Agricultural Editor JOHN C. JOHNSTON. Chief Clerk

\section{AGRONOMY}

R. J. Garber, Ph. D.

T. E. Odland, M. S. Associate Agronomist

T. C. McIlvaine, Ph. D.

Assistant Agronomist

K. S. Quisenberry, B. S.*** Junior Agronomist

\section{ANIMAL HUSBANDRY}

E. A. Livesay, M. S.***

Animal Husbandman

Chas. V. Wilson, M. S.

Assistant Animal Husbandman

E. C. Stillwell, M. S.

Assistant Animal Husbandman

S. S. Wheeler, M. S.

Junior Animal Husbandman

R. H. Tuckwiller, B. S. Agr.*

Assistant Animal Husbandman

\section{CHEMISTRY}

Henry G. Knight, Ph. D. Chemist Chas. E. Weakley, Jr., B. A.,

T. B. Leith, B. A.**

T. J. Cochran, B. S.

Assistant Chemist

Junior Chemist

\section{DAIRY HUSBANDRY}

Ernest L. Anthony, M. S. Agr.

Dairy Husbandman

H. O. Henderson, M. S. Agr.***

Associate Dairy Husbandman

Warren Gifford, B. S. Agr.

Junior Dairy Husbandman

G. M. Trout, M. S.

Assistant in Dairy Husbandry

\section{ENTOMOLOGY}

L. M. Peairs, M. S. Entomologist W. E. Rumsey, B. S.

\section{Asistant Entomologist}

\section{FARM ECONOMICS}

A. J. Dadisman, Ph. D.

Farm Economist

W. W. Armentrout, B. S.

Junior Farm Economist

F. D. Cornell, M. S.

Junior Farm Mechanician

HORTICULTURE

M. J. Dorsey, Ph. D.

H. L. Crane, M. S. Agr.

Horticulturist

H. E. Knowlton, Ph. D.

Associate Horticulturist

Assnciate Horticulturist

K. C. Westover, M. S. Agr.***

Assistant Horticulturist Ernest Angelo, B. S. Agr.

Junior Horticulturist

L. F. Sutton, B. S. Agr.t

Assistant Horticulturist

Troy M. Currence, B. S. Agr.

Assistant in Horticulture

Lewis G. Stark, B. S. Agr.

Assistant in Horticulture

\section{PLANT PATHOLOGY}

N. J. Giddings, Ph. D.

Anthony Berg, B. S.

Plant Pathologist

Assistant Plant Pathologist

L. H. Leonian, Ph. D.

Assistant Plant Pathologist

E. C. Sherwood, M. S.

Assistant Plant Pathologist

\section{POULTRY HUSBANDRY}

Horace Atwood, M. S. Agr.

Poultry Husbandman

SOILS

E. P. Deatrick, Ph. D.

Associate Soil Technologist

\footnotetext{
- In co-operation with the U. S. Department of Agriculture, Washington, D. C.

* In co-operation with the State Department of Agriculture, Chareston, W. Va.

* On leave of absence.

In co-operation with the Reymann Memorial Farms, Wardensville, W. Va.

In charge of the Maggie Sub-Station, Maggie, W. Va.
} 


\section{The Influence of Plot Size and Replication on Experimental Error in Field Trials with Potatoes}

The use of the probable error as a measure of reliability for field plot experiments has been given much attention since the publications of Wood and Stratton (1),* and Mercer and Hall (2); however, that attention has been devoted principally to the cereal crops with some few papers available on field crops other than cereals, and on tree fruits and bush fruits. Almost no information is available on field technic as applied to the potato. The experiments which have been reported, and they have been carried on in nearly all parts of the world where the crop has been successfully grown, have had to do almost entirely with variety tests, cultural treatments, seed selection, etc., with little thought given to field plot technic, (size, shape, and replication) except in so far as size was compatible with labor convenience.

The potato is rapidly approaching the status of a "cash crop" in some sections of West Virginia and this increasing importance necessitates more careful attention to field experiments with this crop. A search for information concerning plot technic as applied to this crop showed that very little work has been done. This study was accordingly made at the West Virginia Agricultural Experiment Station Horticultural Farm, Morgantown, West Virginia, in 1.22 and 1923, to determine the size of single-row potato plot and the number of replications necessary to reduce experimental error to practical limits.

* See references on page 32 of this bulletin. 


\section{LITERATURE REVIEW}

Mitscherlich (3) published the results of experiments designed to determine the optimum plot size for potato field experiments. In one experiment five varieties were used. Four different sizes of plots were chosen, ranging from 3.6 (38.8 sq. ft.) to 237.6 square meters $(2,557.5 \mathrm{sq}$. ft.) and to overcome soil differences he replicated four times. In another similar experiment three different fertilizer treatments were applied with a check and these were replicated four times. On the basis of the probable error of a single determination for yield as determined by Peters' formula this author considers a plot size of fifty-square meters (538.2 sq. ft.), sufficient to give a reasonable degree of accurancy.

Chittenden (4) maintains that "place" is important in the comparison of potato yields and that this should be carefully considered. He arranged eight pairs of plots of three rows each, in such a manner that the members of a pair were separated from each other by a distance silghtly greater than that separating the rows between the plots. The pairs of plots were in turn separated from each other by a distance somewhat greater than that between the plots in a pair. The yields of the plants of the outside rows were used as a basis for comparing the yields of plants differently "placed". It was found that plants located on the outer corners of the plots yielded highest, those in the outer rows ranked next while those at the ends of the inside rows and those in the inside rows followed in order.

Wilson and Chittenden(5)conducted planting experiments employing nine spacings at first and subsequently sixteen spacings, with plants nine to eighteen inches in the row. They concluded from their results that (a) the greater the space available for the individual plant the greater the yield of the individual plant is likely to be; and (b) the greater the number; of plants per acre the greater the yield. They also concluded that in addition to'spacing, seed source, temperature, and soil moisture are important factors influencing yields.

Stewart $(6,7)$ studied the effect of missing hills on the yield of adjacent hills. He halved 360 tubers longitudinally and the halves of one tuber were placed in the same group with 
the halves of a second tuber and spaced fifteen inches apart in the row. The halves of two tubers formed a group of four hills. These successive groups were separated by a missing hill (thirty inches) so that one plant in each of the two adjacent groups adjoined a missing hill. The rows were spaced thirty-six inches apart. The data obtained from 351 pairs of plants showed that on the average, each plant adjoining a missing hill produced 23.2 per cent greater than plants which were not so situated. Also halves of the same tubers were planted opposite each other in adjacent rows and the yields of 85 pairs of these hills, grown from related halves, showed a difference ranging from 0 to 66.7 per cent. Both of these experiments were repeated the following year, with the addition of a planting in which three missing hills (sixty inches) occurred. He found that 53.8 per cent of the loss in yield was made up by the plants adjoining single missing hills and 43.8 per cent was made up in the case of the triple missing hills. Statistically the difference in effect between single and triple hill misses was not significant. He used the yields of 145 and 129 pairs of plants respectively for this data.

Stewart (7) repeated in greater detail his investigations of the variation in yield of the different halves of the same tuber. He selected tubers weighing from $31 / 4$ to $33 / 4$ ounces, and before planting reduced all to $31 / 4$ ounces in weight by removing slices from the stem end of the larger tubers. At the time of planting the tubers were cut lengthwise in halves and these were planted fifteen inches apart in the row. . Data was obtained from 429 pairs of plants and the difference in yield varied from 0 to 141.8 per cent of the mean yield of the two plants of a pair. The average variation was 23.4 per cent. The author pointed out that conclusions should not be drawn from the yields of a small number of plants regardless of the care taken "to secure parallel conditions for growth." Stewart also made yield comparisons with whole small tubers and cut pieces of equal weights from the large tubers of the same plant (8).

The results of this experiment are slightly contradictory of those obtained in the first two experiments devoted to this study but not sufficiently so to be of any real significance. This third experiment indicates conclusively that the small tubers give the better yields. The author recommends small 
tubers one to two ounces in weight as being as good as, if not better than, cut pieces of equal weight taken from large tubers of the same plant.

Fitch and Bennett's (9) conclusions agree in general with the results of Stewart. They found that approximately fifty per cent of the loss in yield due to missing hills was made up by the yields of the adjoining hills.

Brown (10) reported the results of six years of work at Storrs, Connecticut. Single rows 103.7 feet in length were used for variety and strain testing. All were planted by a two-man, Iron-Age planter which dropped the seed pieces twelve inches apart in the row. The rows were spaced three feet apart. The same strain of Green Mountain was used in all checks which occurred every fifth row except in 1919 when they came at ten row intervals. There were 137 checks and each was flanked on both sides by plots. The natural productivity of the soil varied considerably but was not supposed to have influenced the yields of the checks any more than it did the flanking plots. The yields of the adjacent plots were averaged and compared in each case with the check. No significant correlation was found; hence, as Brown reported, there was no competition between single-row plots under these conditions.

Meyers and Perry (11) discuss some of the important points to be considered in the analysis and interpretation of data derived from comparative tests with potatoes using data from experiments which have been carried on under the directions of the senior author for several years and also the published data of other investigators. The influence of competition upon the relative yields of hills planted from apical and basal parts of the same tuber was studied and the former were found to yield more than the latter by about fifteen per cent. There was also an effect of competition between hills planted with the apical parts of tubers and those planted with the basal parts. This effect of competition varied with varieties. There was a high positive correlation between plants from the same tubers with respect to (a) the numbers of tubers per hill, (b) average weight of tubers, and (c) the number of stems per hill. This correlation was less for plants from different tubers as is shown by the 
fact that the significance of the difference between the correlation coefficients for the characters mentioned, determined by Student's Method,* gave odds of 4,999 to 1 in favor of the related plants. However, these authors point out that this significance was less pronounced for those characters affecting yield and influenced greatly by soil conditions. By analyzing Stewart's data $(6,7)$ Meyers and Perry show that there was a significant difference, based on the coefficient of correlation, between pairs of hills from the same tubers, and pairs of hills from different tubers whether the plants were or were not opposite missing hills.

These authors, from two years' data obtained from five hundred plots of different varieties and strains of potatoes, state that a twenty-five hill row having the hills eighteen inches apart in the row and the rows thirty-six inches apart replicated ten times, should be used, although five replications gave "a fair degree of reliability" under the existing conditions.

\section{MATERIALS AND METHODS}

The area for the potato planting of 1922 had been used during the preceeding years in vegetable fertilizer tests. The boundaries of the plots were obscure, as three years had elapsed since the tests were completed. A general description of the plot layout was obtained and it is certain that the entire planting for the present study was within the area formerly occupied by the fertilizer experiment also that the rows of the present planting extended at right angles to the long axes of the test plots of the earlier experiment. The area sloped gently toward the east.

The four strains of Carman No. 3 potatoes used in these experiments were obtained from Minnesota (certified), Canada (donated by the Ontario Department of Agriculture), Pickens, W. Va., and from Little Falls, W. Va. They were all considered to be true to variety and of high yjelding capacity. Hereafter they will be designated in this paper as "Minnesota Carmans", "Canadian Carmans", "West Virginia High Altitude Carmans", and "West Virginia Low Altitude Carmans". (See Figure 1). The two latter strains were produced at approxi-

* Student, Biometrika $6: 1-25,1918$. ibid. $11: 414-417,1917$. Also Love, H. H., A Modification of Student's Table for Use in Interpreting Experimental Results. Jour. Am. Soc. Agr. $16: 68-73,1924$. 
mate altitudes of 2,200 and 1,200 feet respectively.

The seed stock was cut by one person, and the planting was done by a two-man Iron-Age planter drawn by a tractor. The planter spaced the seed pieces ten to twelve inches in the row, and the tractor tread necessitated 3.5 feet spacing between the rows. The strains were planted separately, one being continuous with the other in the rows. Complete trips were made with the planter; i. e. planting was continuous down one row and back the next. The direction of planting is indicated by small arrow heads in Figure I. All cultural practices during the growing season were uniform over the entire planted area.

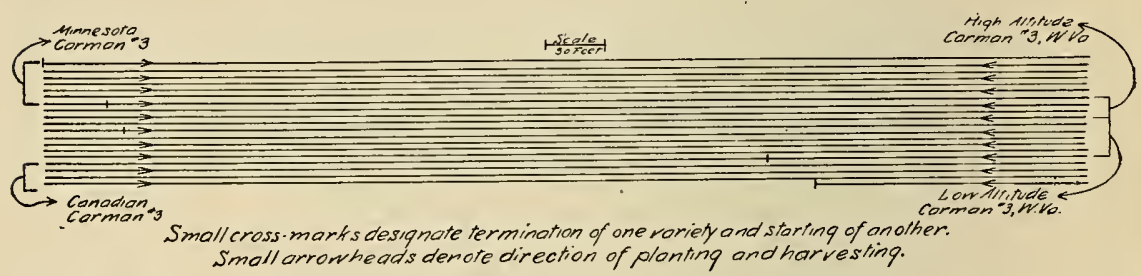

Fig. 1.-Plan of the Potato Planting at the State Horticultural Farm, Morgantown, West Virginia, 1922.

The tubers were harvested with a plow-type shaker-digger drawn by a tractor. The digger had been adjusted previously and very few tubers were missed. The total yields of consecutive ten-foot lengths were taken to the nearest quarter of a pound and the harvesting throughout followed the sequence of planting. A narrow strip of about four feet in width was discarded at each end of the planting to eliminate "border influence."

There were fifty-one, one-twentieth acre plots within the area used for the 1923 planting, the yields of which served to show in general the natural variability of the area (Figure 2). Carman No. 3 potatoes grown at Elkins, West Virginia, were used for seed. This stock had been selected for a number of years for trueness to variety and high yielding qualities and was considered suitable for the purpose. Planting, care duririg the growing season, harvesting, and taking of data were performed in much the same manner as the 1922 planting, except that the ten-foot plot vields were taken to the nearest one-half pound instead of the nearest one-fourth pound. The yields of 
the one-twentieth acre plots were recorded separately to serve as, a measure of soil variability. This is indicated in Figure 2 by super-imposing a graph of the plot yields over the map of the area (inclosed in dotted lines) in such a manner as to indicate the yields within the plots on which they occurred. In general, the larger yields were in the lower parts of the area, with the exception of the lowest tier of plots in which the smaller yields were from soils having a hardpan subsoil which affected drainage.

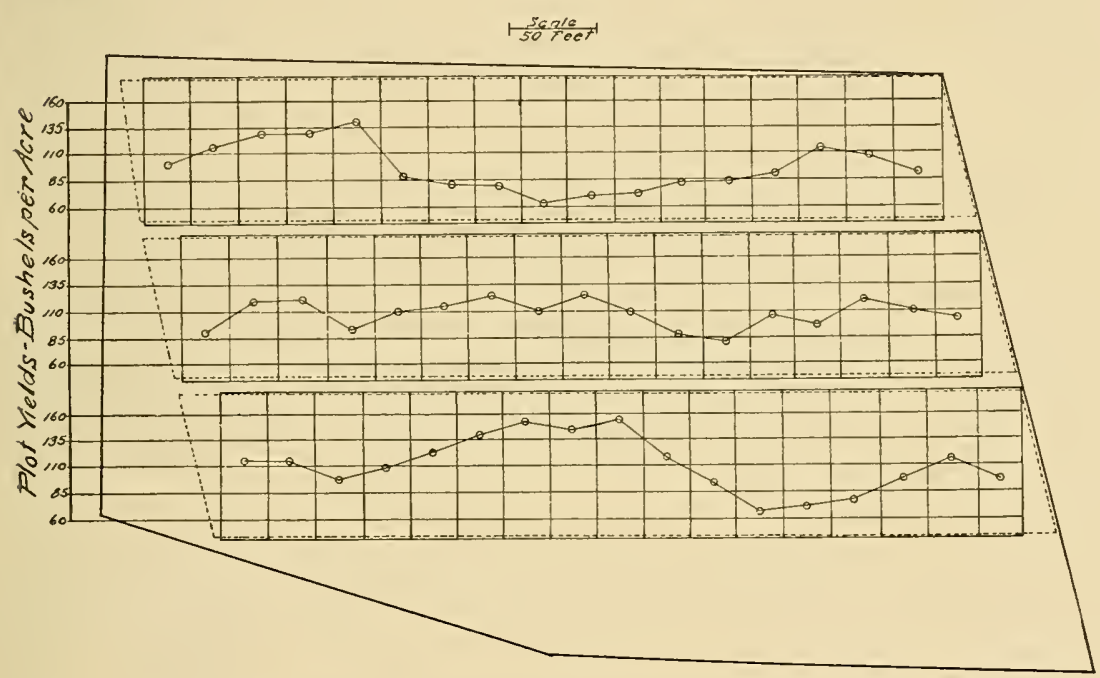

Fig. 2.-Map of the Potato Planting at the State Horticultural Farm, Morgantown, West Virginia, 1923.

\section{DETERMINATION OF SINGLE-ROW PLOT SIZE}

The yields of the ten-foot single-row plots for both 1922 and 1923 were computed to a bushels-per acre basis, assuming that sixty pounds make a bushel. The yields of the various sized plots considered in this study were obtained by combining the yields of consecutive ten-foot plots. In 1922, six different sized plots, the largest being sixty feet long, were considered for each strain of potatoes used, while in 1923 twelve different sized plots were considered. In this latter case the plot sizes varied by ten-foot lengths until one hundred-foot plots were reached after which one hundred twenty- and one hundred fifty-foot plots were formed. Frequencies were made from the yields of 
the various sized plots according to the strain of seed stock. From these frequencies the standard deviation and the probable error of a single determination were calculated in each instance by the ordinary method.* Also, the curves for the theoretical probable errors were plotted on the assumption that the probable error decreases as the square root of the number of variates or as the size of the sample increases.

The comparison of different sized plots was based on their respective standard deviations. A difference in the standard deviations of compared plots was not considered as significant unless it was equal to three or more times its probable error. Figure 11 gives for each study the plot sizes compared as well as the significance of the differences.

\section{DETERMINATION OF EFFECT OF REPLICATION}

In order to determine the effect of replication on the reduction of experimental error the average of the yields, in bushels per acre, of varying numbers of systematically distributed fortyfoot single-row plots of the 1923 planting were used to form the frequencies. The data taken in 1922 were inadequate for this purpose.

The distribution of the plots was dependent on the number of replications under consideration. For example, suppose the yields of one hundred consecutive plots were available and a frequency distribution for one replication was desired. The average of the yields of the first and the fifty-first plots would be the first variate, that of the yields of the second and the fiftysecond would be the second, etc., until all the plot yields available were used in combination. Should a frequency distribution of four replications be desirable the average of the yields of the first, the twenty-first, the forty-first, the sixty-first and the eighty-first plots would become the first variate; that of the yields of the second, the twenty-second, the forty-second, the sixty-second, and the eighty-second, would become the second variate, etc., until all the plot yields available were used in combination.

* The formulae of the ordinary method of deriving the standard deviation and the probable error of a singlc determination are: $\sqrt{\frac{\sum f d}{n}}$ and $0.6745 \sqrt{\frac{\Sigma_{n} d^{2}}{n}}$ when $\Sigma$ indicates summation, $f$ the frequency, $\mathrm{d}^{2}$ the deviation from the mean squared, and $\mathrm{n}$ the number of individuals composing the frequency distribution. 
The number of replications studied ranged from one to seven in the first analysis and from one to five in the second analysis. Computations for the same statistical constants were made and like comparisons drawn as for the studies dealing with the single-row plot sizes.

\section{ANALYSIS OF DATA.}

Since there were several strains planted in 1922 and but one in 1923, and since the largest plots considered in 1922 were sixty feet in length, whereas the largest plots considered in the year following were a hundrea and fifty feet in length, it would seem convenient to analyze the data according to the year in which it was taken.

TABLE I.-The Influence of Size of Plot on the Reduction of the Experimental Error. Summarized Data for Minnesota Carman No. 3 Potatoes (1922).

\begin{tabular}{|c|c|c|c|c|c|c|}
\hline \multirow{3}{*}{$\begin{array}{c}\text { Classes } \\
\text { Bu. per } \\
\text { Acre }\end{array}$} & \multicolumn{6}{|c|}{ Length of Row } \\
\hline & $10 \mathrm{ft}$. & $20 \mathrm{ft}$. & $30 \mathrm{ft}$. & $4.0 \mathrm{ft}$. & $50 \mathrm{ft}$. & $60 \mathrm{ft}$. \\
\hline & \multicolumn{6}{|c|}{ Frequencies } \\
\hline $\begin{array}{r}41.6 \\
52.0 \\
62.4 \\
72.8 \\
83.2 \\
93.6 \\
104.0 \\
114.4 \\
124.8 \\
135.2 \\
145.6 \\
156.0 \\
166.4 \\
176.8 \\
187.2 \\
197.6 \\
208.0 \\
218.4 \\
228.8 \\
239.2 \\
249.6 \\
260.0 \\
270.4 \\
280.8 \\
291.2 \\
\end{array}$ & $\begin{array}{r}3 \\
1 \\
2 \\
4 \\
12 \\
10 \\
18 \\
20 \\
26 \\
14 \\
28 \\
21 \\
26 \\
12 \\
25 \\
19 \\
12 \\
9 \\
8 \\
8 \\
5 \\
3 \\
1 \\
2 \\
1 \\
\end{array}$ & $\begin{array}{r}1 \\
\\
2 \\
4 \\
5 \\
12 \\
10 \\
6 \\
17 \\
8 \\
7 \\
16 \\
13 \\
12 \\
12 \\
5 \\
4 \\
3 \\
4 \\
3 \\
1\end{array}$ & $\begin{array}{r}1 \\
3 \\
4 \\
6 \\
9 \\
2 \\
10 \\
8 \\
5 \\
13 \\
7 \\
12 \\
3 \\
5 \\
3 \\
3 \\
1 \\
1\end{array}$ & $\begin{array}{l}2 \\
3 \\
3 \\
6 \\
7 \\
6 \\
3 \\
2 \\
9 \\
8 \\
7 \\
7 \\
3 \\
4 \\
\\
1\end{array}$ & $\begin{array}{r}1 \\
4 \\
2 \\
5 \\
4 \\
6 \\
4 \\
3 \\
3 \\
5 \\
11 \\
3 \\
3 \\
2 \\
2\end{array}$ & $\begin{array}{l}3 \\
5 \\
2 \\
3 \\
4 \\
2 \\
4 \\
3 \\
6 \\
6 \\
4 \\
3 \\
1 \\
1\end{array}$ \\
\hline $\mathrm{n}$ & 290 & 145 & 96 & 71 & 58 & 47 \\
\hline$\overline{\mathrm{M}} \pm \mathrm{Em}$ & $156.6 \pm 1.9$ & $154 . \overline{5} \pm 2.5$ & $157.2 \pm 2.9$ & $158.8 \pm 3.2$ & $157.8 \pm 3.4$ & $157.8 \pm 3.7$ \\
\hline$\overline{\Sigma f d^{2}}$ & 6592 & 2577 & 1631 & 1068 & 302 & 630 \\
\hline$\overline{\sigma \pm \mathrm{E} \sigma}$ & $48.6 \pm 1.4$ & $43.8 \pm 1.7$ & $41.9 \pm 2.0$ & $39.6 \pm 2.2$ & $38.6 \pm 2.4$ & $38.0 \pm 2.6$ \\
\hline$E_{s}$ & 32.8 & 29.6 & 28.2 & 26.7 & 26.1 & 25.7 \\
\hline
\end{tabular}




\section{DETERMINATION OF SIZE OF SINGLE-ROW PLOT The Studies of 1922}

The summary of the data from the "Minnesota Carmans" in Table I shows that the populations of the frequencies range from 290 with the smallest plots to 47 with the largest plots. Also, that a reduction in the probable error of a single determination of 7.1 bushels per acre occurred as a result of the increase in plot size.

It is interesting to note that eighty-six per cent of this reduction occurred from increasing the plot size from ten to forty feet. Figure 11 (a) shows that the first significant difference between standard deviations is found in the comparison of the ten- and the forty-foot plots and that a significant difference is not found again with the larger plots of this study. Curves of the actual and the theoretical probable errors of a single determination are shown in Figure 3.

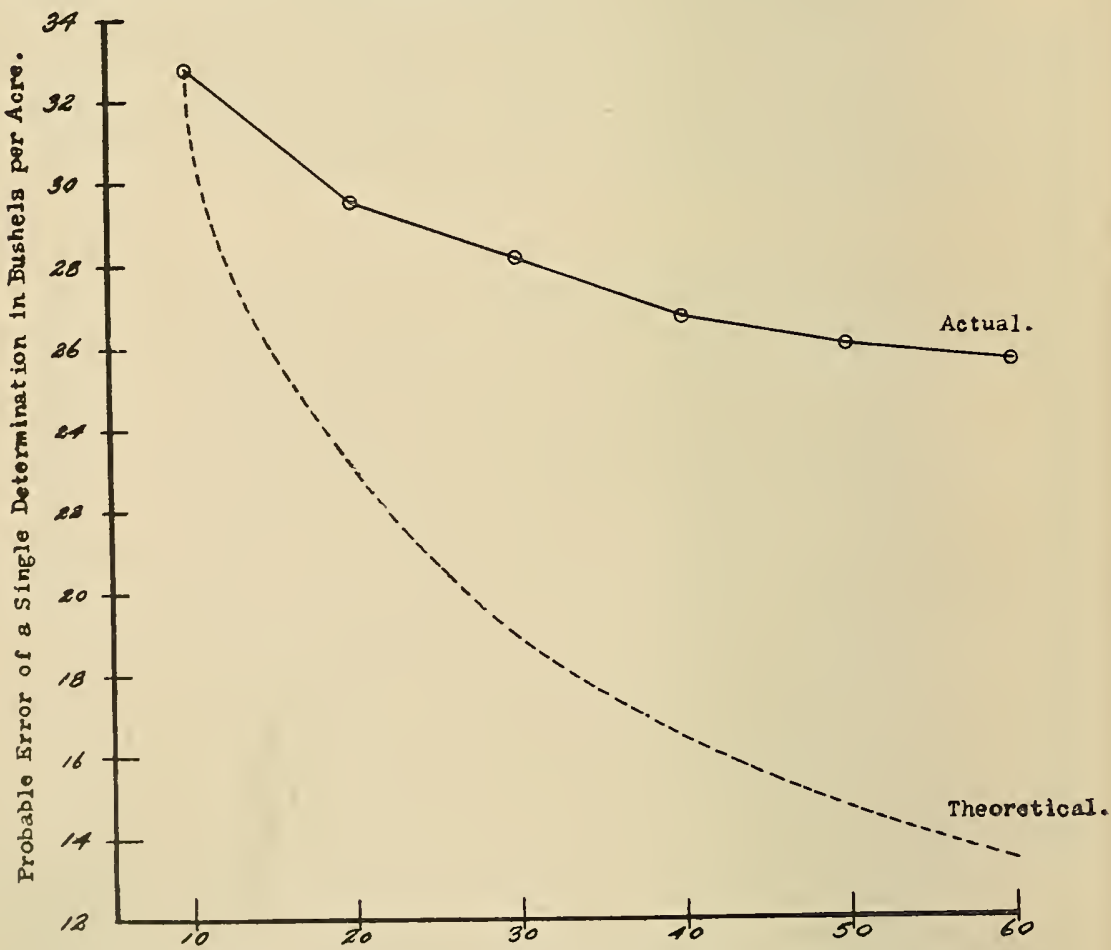

Fig. 3. - The Curves of the Actual and the Theoretical Probable Errors for Varying Row Lengths of Minnesota Carman No. 3 Potatoes Grown in 1922 . 
The wide divergence between the curves can be attributed largely to soil heterogeneity. From this study it may be concluded that little is to be gained by using a single-row plot of greater length than forty feet.

Table II summarizes the data of the "West Virginia High Altitude Carmans". The populations of the different plot lengths considered ranged from 186 in the ten-foot plots to 30 in the sixty-foot plots.

TABLE II.-The Influence of Size of Plot on the Reduction of the Experimental Error. Summarized Data for West Virginia Carman No. 3 Potatoes (High Altitude-1922).

\begin{tabular}{|c|c|c|c|c|c|c|}
\hline \multirow{3}{*}{$\begin{array}{c}\text { Classes } \\
\text { Bu. per } \\
\text { Acre }\end{array}$} & \multicolumn{6}{|c|}{ Length of Row } \\
\hline & $10 \mathrm{ft}$. & $20 \mathrm{ft}$. & $30 \mathrm{ft}$ & $40 \mathrm{ft}$. & $50 \mathrm{ft}$. & $60 \mathrm{ft}$. \\
\hline & \multicolumn{6}{|c|}{ Frequencies } \\
\hline $\begin{array}{r}72.8 \\
83.2 \\
93.6 \\
104.0 \\
114.4 \\
124.8 \\
135.2 \\
145.6 \\
156.0 \\
166.4 \\
176.8 \\
187.2 \\
197.6 \\
208.0 \\
218.4 \\
228.8 \\
239.2 \\
249.6 \\
260.0 \\
270.4 \\
280.8 \\
291.2 \\
301.6 \\
312.0 \\
322.4 \\
332.8 \\
343.2 \\
353.6 \\
364.0 \\
374.4 \\
\end{array}$ & $\begin{array}{r}1 \\
3 \\
2 \\
8 \\
6 \\
7 \\
10 \\
10 \\
14 \\
8 \\
12 \\
15 \\
12 \\
19 \\
15 \\
13 \\
9 \\
8 \\
3 \\
3 \\
2 \\
3\end{array}$ & $\begin{array}{r}2 \\
2 \\
1 \\
3 \\
7 \\
7 \\
5 \\
7 \\
4 \\
9 \\
7 \\
10 \\
11 \\
7 \\
3 \\
5 \\
1 \\
2\end{array}$ & $\begin{array}{l}3 \\
1 \\
1 \\
3 \\
4 \\
5 \\
3 \\
6 \\
5 \\
7 \\
5 \\
8 \\
6 \\
1 \\
1 \\
1 \\
1\end{array}$ & $\begin{array}{l}2 \\
2 \\
2 \\
2 \\
1 \\
6 \\
5 \\
3 \\
3 \\
5 \\
9 \\
1 \\
2 \\
2\end{array}$ & $\begin{array}{l}1 \\
1 \\
1 \\
2 \\
3 \\
6 \\
2 \\
1 \\
7 \\
2 \\
6 \\
1 \\
1 \\
2\end{array}$ & $\begin{array}{l}1 \\
1 \\
3 \\
1 \\
3 \\
4 \\
1 \\
6 \\
3 \\
4 \\
2\end{array}$ \\
\hline $\mathrm{n}$ & 186 & 93 & 61 & 45 & 36 & 30 \\
\hline $\mathrm{M} \pm \mathrm{Em}$ & $217.8 \pm 2.5$ & $218.1 \pm 3.0$ & $217.7 \pm 3.3$ & $219.3 \pm 3.7$ & $218.7 \pm 4.2$ & $219.4 \pm 3.8$ \\
\hline$\overline{s d 2}$ & 5115 & 1573 & 848 & 558 & 607 & 269 \\
\hline$\overline{\sigma \pm \mathrm{E} \sigma}$ & $49.7 \pm 1.7$ & $42.8 \pm 2.1$ & $38.8 \pm 2.4$ & $36.6 \pm 2.6$ & $37.1 \pm 3.0$ & $31.1 \pm 2.7$ \\
\hline $\mathrm{Es}_{\mathrm{s}}$ & 33.6 & 28.9 & 26.2 & 24.7 & 25.0 & 21.0 \\
\hline
\end{tabular}


The reduction in the probable error, due to increase of plot size, between these extreme plot lengths was 12.6 bushels per acre, thirty-seven per cent of which occurred between the tenand the twenty-foot plots and seventy-one per cent of which occurred as a result of increasing the plot length to forty feet. Figure 11 (b) shows that the first significant difference in standard deviations was between the ten- and the twenty-foot plots and the second significant difference between the twentyand the sixty-foot plots. The curves of the actual and the theoretical probable errors shown in Figure 4 are in general similar to those of the "Minnesota Carmans."

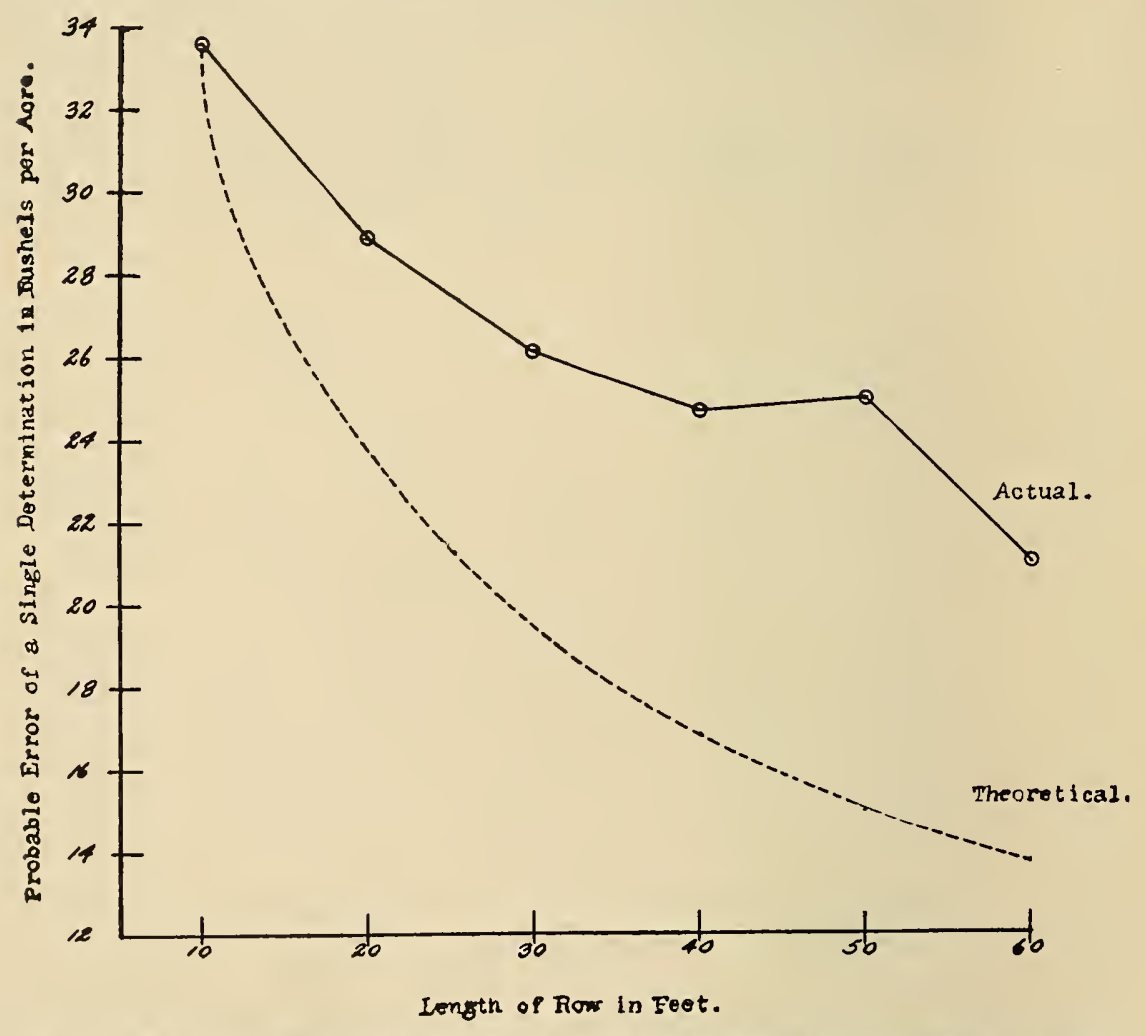

Fig. 4.-The Curves of the Actual and the Theoretical Probable Errors for Varying Row Length of West Virginia (High Altitude) Carman No. 3 Potatoes Grown in 1922.

This study indicated that under the existing conditions reasonable accuracy may be expected from the use of a twenty-foot single-row plot and that significantly greater accuracy is possi- 
ble by the use of a sixty-foot plot.

The populations for "Canadian Garmans" plots varied as a result of increase in plot size, from 192 for the ten-foot plots to 31 for the sixty-foot plots. This is shown in data summarized in Table III.

TABLE III.-The Influence of Size of Plot on the Reduction ot the Experimental Error. Summarized Data for Canadian Carman No. 3 Potatoes (1922).

\begin{tabular}{|c|c|c|c|c|c|c|}
\hline \multirow{3}{*}{$\begin{array}{c}\text { Classes } \\
\text { Bu. per } \\
\text { Acre }\end{array}$} & \multicolumn{6}{|c|}{ Length of Row } \\
\hline & $10 \mathrm{ft}$. & $20 \mathrm{ft}$. & $30 \mathrm{ft}$ & $40 \mathrm{ft}$ & $50 \mathrm{ft}$. & $60 \mathrm{ft}$. \\
\hline & \multicolumn{6}{|c|}{ Frequencies } \\
\hline $\begin{array}{r}20.8 \\
31.2 \\
41.6 \\
52.0 \\
62.4 \\
72.8 \\
83.2 \\
93.6 \\
104.0 \\
114.4 \\
124.8 \\
135.2 \\
145.6 \\
156.0 \\
166.4 \\
176.8 \\
187.2 \\
197.6 \\
208.0\end{array}$ & $\begin{array}{r}2 \\
7 \\
6 \\
6 \\
8 \\
12 \\
18 \\
17 \\
19 \\
21 \\
22 \\
15 \\
16 \\
7 \\
2 \\
4 \\
2 \\
5 \\
3\end{array}$ & $\begin{array}{r}2 \\
4 \\
4 \\
6 \\
6 \\
12 \\
7 \\
14 \\
10 \\
9 \\
9 \\
5 \\
4 \\
2 \\
\end{array}$ & $\begin{array}{l}1 \\
1 \\
3 \\
5 \\
4 \\
6 \\
7 \\
7 \\
9 \\
8 \\
5 \\
4 \\
\\
1 \\
1\end{array}$ & $\begin{array}{r}1 \\
3 \\
3 \\
3 \\
3 \\
3 \\
13 \\
4 \\
7 \\
3 \\
2 \\
1\end{array}$ & $\begin{array}{l}2 \\
4 \\
1 \\
5 \\
6 \\
5 \\
4 \\
3 \\
5 \\
1 \\
2\end{array}$ & $\begin{array}{l}1 \\
2 \\
3 \\
2 \\
6 \\
5 \\
2 \\
4 \\
6\end{array}$ \\
\hline$n$ & 192 & 95 & $62 \quad 1$ & 46 & 38 & 31 \\
\hline$\overline{\mathrm{M}} \pm \mathrm{Em}$ & $108.8 \pm 2.0$ & $112.8 \pm 2.4$ & $112.4 \pm 2.7$ & $113.3 \pm 2.9$ & $112.2 \pm 3.2$ & $112.7 \pm 3.0$ \\
\hline$\Sigma \mathrm{fd}^{2}$ & 3354 & 1132 & 570 & 367 & 320 & 202 \\
\hline$\sigma \pm \mathrm{E} \sigma$ & $40.4 \pm 1.4$ & $34.4 \pm 1.7$ & $31.5 \pm 1.9$ & $29.3 \pm 2.1$ & $29.0 \pm 2.2$ & $25.1 \pm 2.1$ \\
\hline Es & 27.2 & 23.2 & 21.2 & 19.8 & 19.6 & 16.9 \\
\hline
\end{tabular}

The reduction in probable error between these extreme length plots was 10.3 bushels per acre, fifty-eight per cent of which occurred between the ten- and the thirty-foot plots and seventy-two per cent of which occurred between the ten- and the forty-foot plots.

The curves of the actual and theoretical probable errors as shown in Figure 5 are similar to those of the studies previously mentioned.

A significant difference in standard deviation was obtained between the ten- and the thirty-foot plots but cannot be found between the thirty-foot plots and the larger plots considered in the study. This is shown in Figure 11 (c). It would seem in 
this instance that the use of a thirty-foot plot would be sufficient for reasonable accuracy.

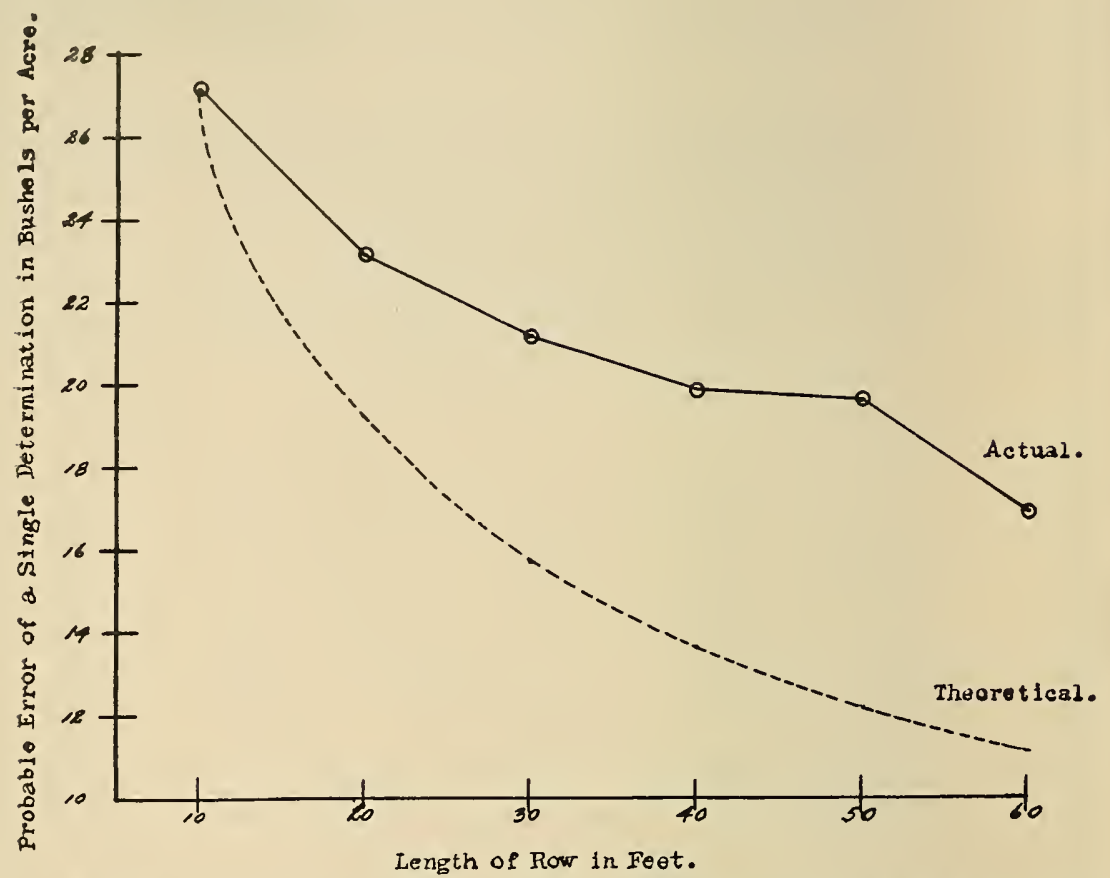

Fig. 5.- The Curves of the Actual and the Theoretical Probable Errors for Varying Row Lengths of Canadian Carman No. 3 Potatoes Grown in 1922 .

The summary of the data of the "West Virginia Low Altitude Carmans" in Table IV shows that the populations for the various plots ranged, owing to increase in size of the plots, from 258 variates in the ten-foot plots to 41 variates in the sixtyfoot plots.

The reduction in probable error between these extremes of plot sizes was 14.8 bushels, of which forty per cent occurred between the ten- and the twenty-foot plots and eighty-three per cent between the twenty- and the forty-foot plots.

The probable error curves (Figure 6) are, again, similar to those of the preceding studies. Here, as in the case of the "W est Virginia High Altitude Carmans" a significant difference in the standard deviation was found between the ten- and the twenty-foot plots and again between the twenty- and the sixty- 
foot plots as shown in Figure 11 (d). The conclusions drawn from this study are identical with those from the study of the "West Virginia High Altitude Carrnans."

TABLE IV.-The Influence of Size of Plot on the Reduction of the Experimental Error. Summarized Data for West Virginia Carman No. 3 Potatoes (Low Altitude-1922).

\begin{tabular}{c|ccccc}
\hline $\begin{array}{c}\text { Classes } \\
\text { Bu.per } \\
\text { Acre }\end{array}$ & $10 \mathrm{ft}$. & $20 \mathrm{ft}$ & $30 \mathrm{ft} \quad 40 \mathrm{ft}$. & $50 \mathrm{ft}$. & $60 \mathrm{ft}$. \\
\cline { 2 - 5 } & \multicolumn{5}{c}{ Frequencies }
\end{tabular}

\begin{tabular}{|c|c|c|c|c|c|c|}
\hline \multicolumn{7}{|c|}{31.2} \\
\hline $\begin{array}{l}41.6 \\
52.0\end{array}$ & $\begin{array}{l}3 \\
2\end{array}$ & 2 & & & & \\
\hline 62.4 & 2 & 2 & 1 & & & \\
\hline 72.8 & 5 & 1 & 1 & & & \\
\hline 83.2 & 5 & 2 & 1 & 1 & 2 & 1 \\
\hline $\begin{array}{r}93.6 \\
1040\end{array}$ & 7 & $\begin{array}{l}3 \\
5\end{array}$ & & 1 & 1 & \\
\hline $\begin{array}{l}104.0 \\
114.4\end{array}$ & $\begin{array}{l}13 \\
15\end{array}$ & $\begin{array}{r}5 \\
11\end{array}$ & $\begin{array}{l}5 \\
5\end{array}$ & $\begin{array}{l}1 \\
3\end{array}$ & $\begin{array}{l}1 \\
2\end{array}$ & \\
\hline $\begin{array}{l}114.4 \\
124.8\end{array}$ & $\begin{array}{l}10 \\
16\end{array}$ & $\begin{array}{r}11 \\
3\end{array}$ & 4 & 4 & 6 & $\begin{array}{l}4 \\
1\end{array}$ \\
\hline $\begin{array}{l}135.2 \\
5.2\end{array}$ & 13 & 8 & 5 & 4 & 4 & 3 \\
\hline 145.6 & 21 & 8 & 3 & 4 & 2 & 4 \\
\hline 156.0 & 22 & 14 & 9 & 4 & 3 & 2 \\
\hline 166.4 & 12 & 7 & 6 & 9 & 4 & 5 \\
\hline 176.8 & 18 & 16 & 9 & 6 & 11 & 4 \\
\hline 187.2 & 17 & 7 & 10 & 7 & & 5 \\
\hline 197.6 & 16 & 7 & 4 & 6 & 4 & 1 \\
\hline 208.0 & 18 & 9 & 5 & 3 & 1 & 4 \\
\hline 218.4 & 8 & 7 & 3 & 2 & 2 & 2 \\
\hline 228.8 & 10 & 3 & 4 & 1 & 1 & 1 \\
\hline 239.2 & 6 & 3 & 3 & 3 & 3 & 1 \\
\hline 249.6 & 3 & 3 & 1 & 1 & 2 & 1 \\
\hline 260.0 & 4 & 1 & 3 & 2 & 2 & \\
\hline 270.4 & 6 & 4 & 2 & & & 2 \\
\hline 280.8 & 4 & 0 & & & & \\
\hline 291.2 & $\begin{array}{l}1 \\
4\end{array}$ & 2 & & & & \\
\hline $\begin{array}{l}301.6 \\
312.0\end{array}$ & $\begin{array}{l}4 \\
2\end{array}$ & 1 & 1 & 1 & & \\
\hline 322.4 & 1 & & & & & \\
\hline $\begin{array}{l}332.8 \\
343.2\end{array}$ & & 1 & & & & \\
\hline 353.6 & 1 & & & & & \\
\hline $\begin{array}{l}364.0 \\
374.4\end{array}$ & 1 & & & & & \\
\hline 384.8 & & & & & & \\
\hline 395.2 & 1 & & & & & \\
\hline$-n$ & 258 & 128 & 85 & 63 & 51 & 41 \\
\hline $\mathrm{M} \pm \mathrm{Em}$ & $170.4 \pm 2.6$ & $17 \overline{2.0 \pm 3.1}$ & $173.9 \pm 3.5$ & $174.8 \pm 3.7$ & $173.1 \pm 4.4$ & $174.8 \pm 4.2$ \\
\hline $\bar{\Sigma} \mathrm{fd}^{2}$ & 9508 & 3309 & 1983 & 1183 & 1028 & 596 \\
\hline$\sigma \pm \mathrm{E} \sigma$ & $61.5 \pm 1.8$ & $52.7 \pm 2.2$ & $48.4 \pm 2.5$ & $43.3 \pm 2.6$ & $46.9 \pm 3.1$ & $39.6 \pm 3.0$ \\
\hline Es & 41.5 & 35.5 & 32.7 & 29.2 & 31.6 & 26.7 \\
\hline
\end{tabular}

A brief survey of the facts ascertained by the analysis of data obtained in the above studies shows that in only one in- 
stance was it necessary to use a single-row plot of forty feet in length to obtain a significant reduction in standard deviation. In both the West Virginia strains significant differences were obtained between the ten-and the twenty-foot plots and again be-

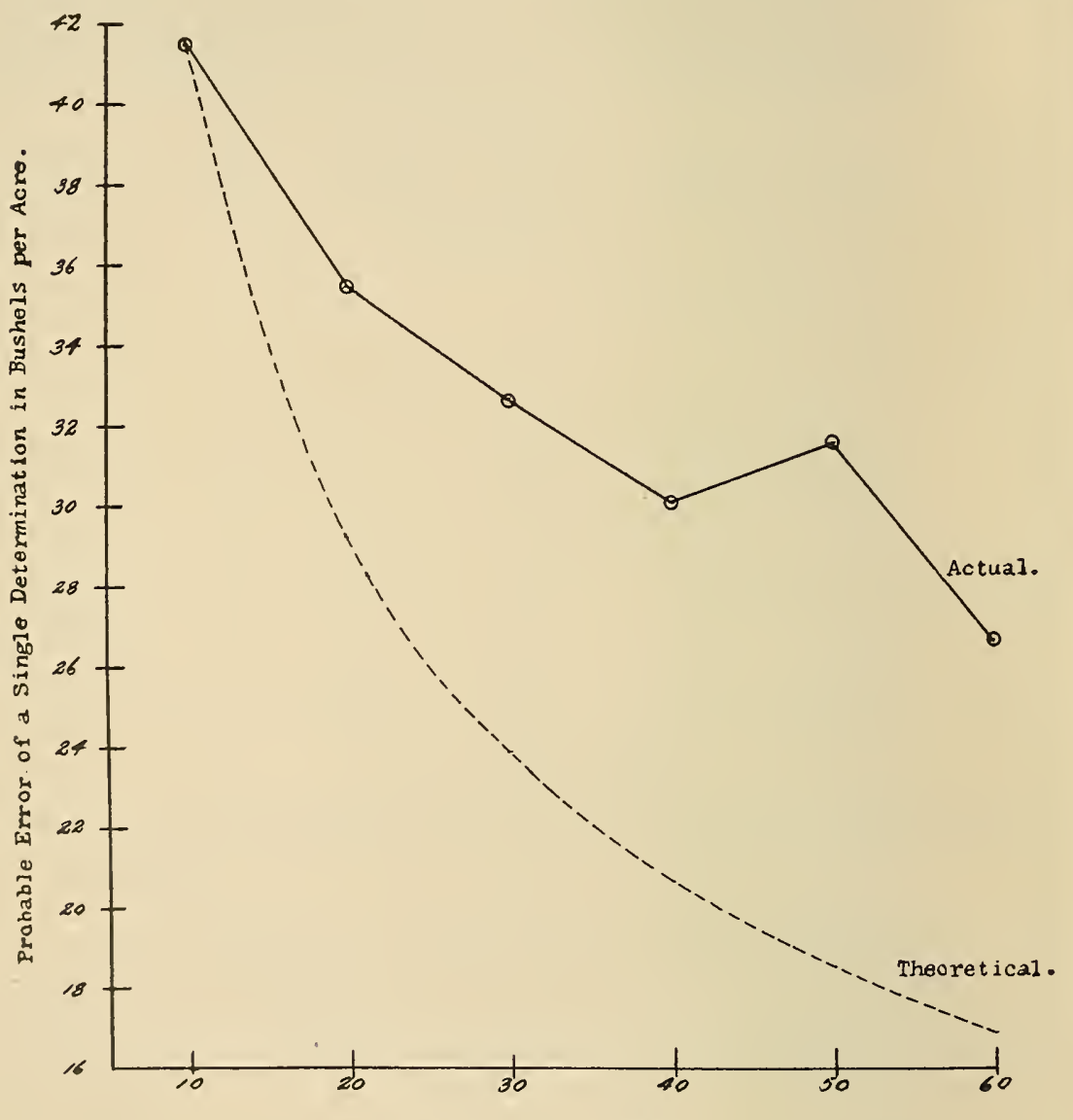

Length of Row in Feet.

Fig, 6. - The Curves of the Actual and the Theoretical Probable Errors for Varying Row Lengths of West Virginia (Low Altitude) Carman No. 3 Potatoes Grown in 1922.

tween the twenty-and the sixty-foot plots. It is of interest to note also that, considering all four of these studies, approximately three-fourths of the probable error reduction between the extreme plot lengths used occurred between the ten- and the forty-foot plots. 


\section{The Study of 1923}

In 1923 the data were subjected to a slightly different analysis. They were first treated as were those of the previous year, and in addition the records from the separate but consecutive ten-foot plots were assembled to show the yields for consecutive hundred and fiftyfoot plots, and the yields from the corresponding portions of the latter were used to derive the frequency distributions. In this way an equal number of variates was obtained for each plot size.

The summary of the 1923 data, treated as were the 1922 studies, is given in Table $\mathrm{V}$. The plots differing in length by ten feet ranged from ten to one hundred feet in length. Plots of a hundred and twenty- and a hundred and fifty-foot lengths are also included. There were 3,309 variates in the ten-foot plot frequency and, owing to the increase in plot size, 220 variates in the hundred and fifty-foot plot frequency.

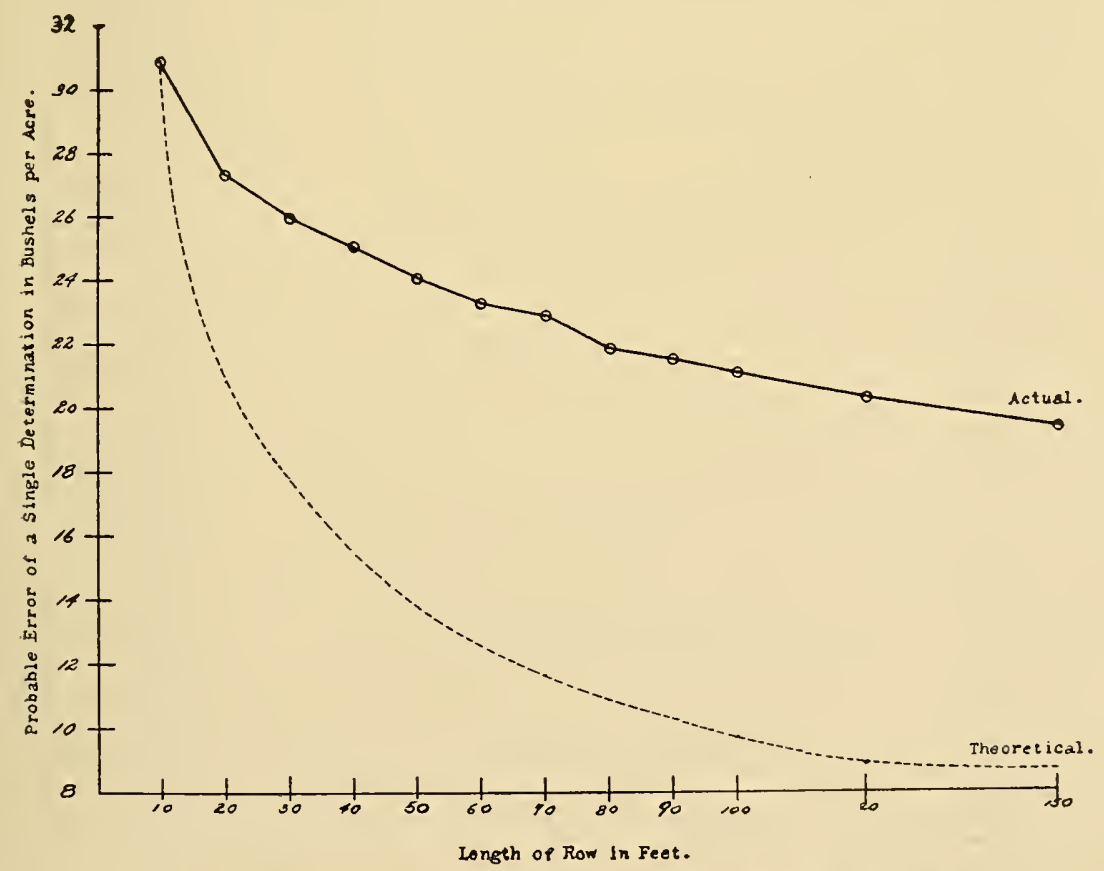

Fig. 7.-The Curves of the Actual and the Theoretical Probable Errors for Varying Row Lengths of West Virginia Carman No. 3 Potatoes Grown in 1923. 


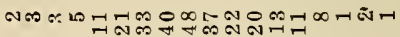

tancm

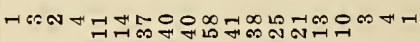

:

बA

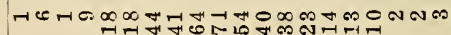

and

-

N

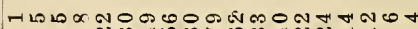

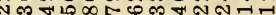

Nedoำ

AL

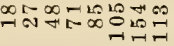

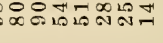

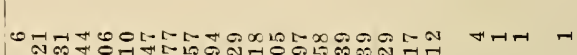

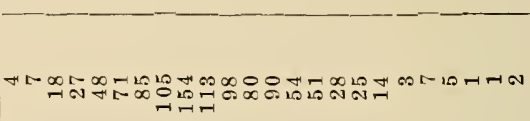

ov 0 - 
The reduction in probable error was 11.5 bushels per acre between the ten, and the hundred and fifty-foot plot sizes. Nearly two-thirds of this reduction occurred between the tenand the sixty-foot plot lengths. The curves for the actual and the theoretical probable errors in Figure 7 are, in so far as the same plot sizes are considered, generally similar to those of the 1922 studies.

A significant difference in standard deviation as shown in Figure 11 (e), was found between the ten and the twenty-foot plots, the twenty- and the forty-foot plots, the forty- and the seventy-foot plots, and between the seventy- and the hundred and twenty-foot plots. In order that the similarity of the results of this study with those of the 1922 studies may be shown, only the plots up to and including the sixty-foot plots were used. The reduction in probable error between the ten- and sixty-foot

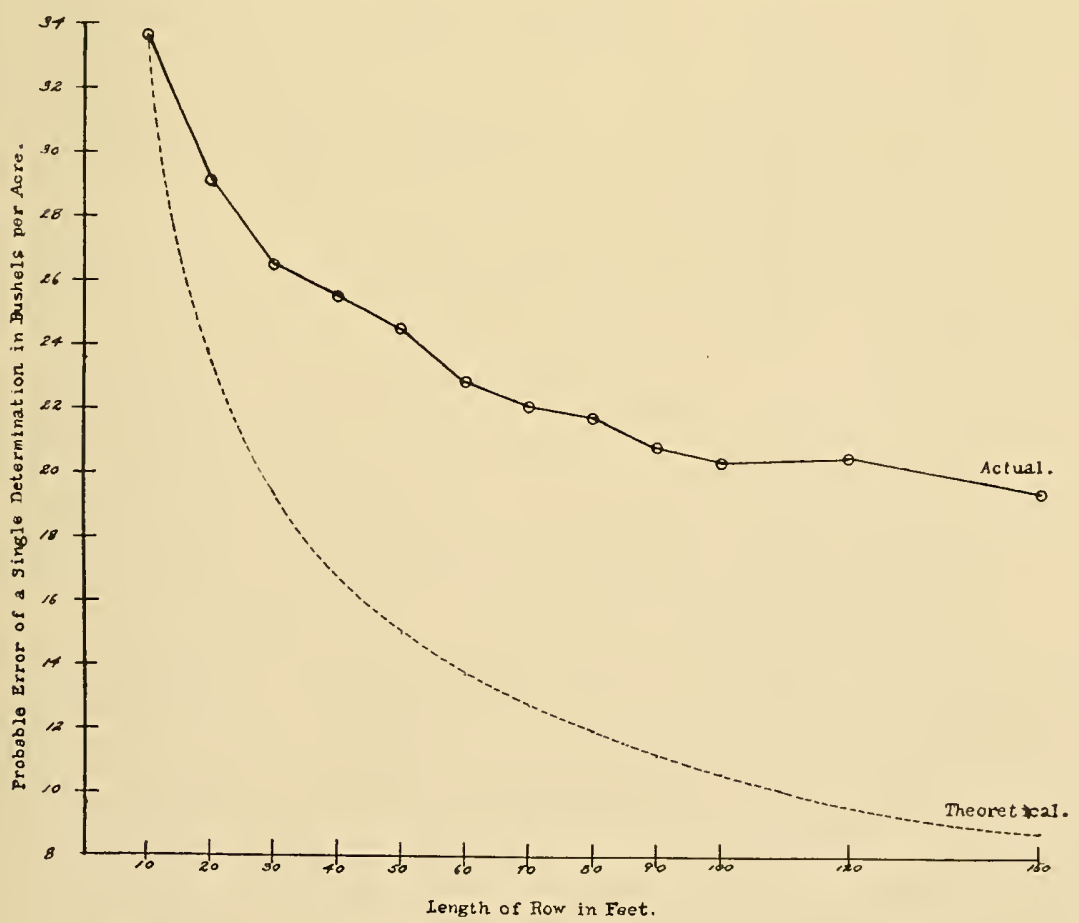

Fig. 8. - The Curves of the Actual and the Theoretical Probable Errors for Corresponding Row Lengths in the Hundred and Fifty-foot Singlerow Plots of West Virginia Carman No. 3 Potatoes Grown in 1923. 
Nhn hming

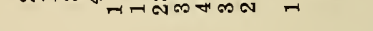

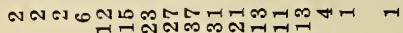

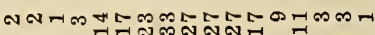

कAनNG

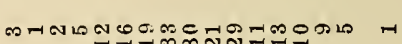

nחल

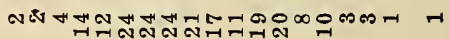

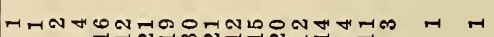

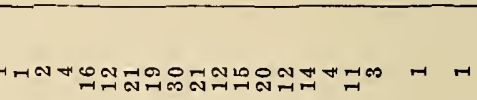

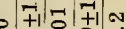
is

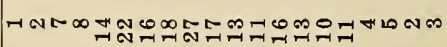

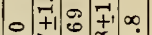

iิ $+1: 0 \begin{array}{ll}+1 & \infty \\ \infty & \infty\end{array}$ :
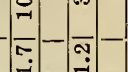

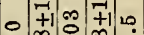

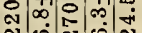

$\begin{array}{llll}0 & 0 & 0 & 0 \\ 0 & 0 & 0\end{array}$
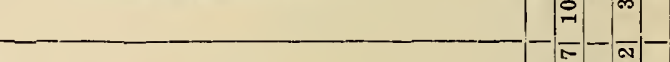

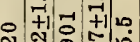

ง ง 殸 
plots was 7.5 bushels per acre, of which forty-seven per cent occurred between the ten- and the twenty-foot plot lengths and seventy-seven per cent between the ten- and the forty-foot plot lengths. The reduction in probable error was closely comparable to that in the 1922 studies.

In the following analysis of the 1923 data the vields of the consecutive ten-foot plots are first combined to make the yields of the hundred and fifty-foot plots of which the vields of corresponding portions are emploved to form the frequencies for the various plot sizes. The same plot sizes are considered as in the foregoing analysis. The frequencies for all plot lengths contained 220 variates.

The total reduction in probable error between the ten-and the hundred and fifty-foot plot sizes was 14.3 bushels per acre of which three-fourths occurred between the ten- and the sixtyfoot plots.

The probable error curves in Figure 8 differ very little from those of the first analysis of this data, and the significance of differences in standard deviation, as shown in Figure 11 (f), between the various plot lengths are the same with one exception; i. e. no significant difference was obtained between the seventyfoot plots and the plots of greater length included in this study. The total reduction in probable error between the ten- and the sixty-foot plots was 10.8 bushels per acre of which forty-one per cent occurred between the ten- and the twenty-foot plots and seventy-five per cent between the twenty- and the forty-foot plots. It is readily seen in this last study that both methods of analysis give practically the same results from which it would seem safe to conclude that there is little to be gained by using a single-row potato plot of more than forty feet in length.

\section{Determination of Effect of Replication}

The summary of the 1923 data to determine the effect of replication on the reduction of experimental error is given in Table VII. The yields of all the consecutive forty-foot singlerow plots are used and the replications considered range from one to seven. The populations vary in number from 821 in the frequency distribution made up of the yields of the single forty-foot plots to 102 in the frequency distribution composed of the average of the yields of the eight similar plots systematically distributed (seven replications). 


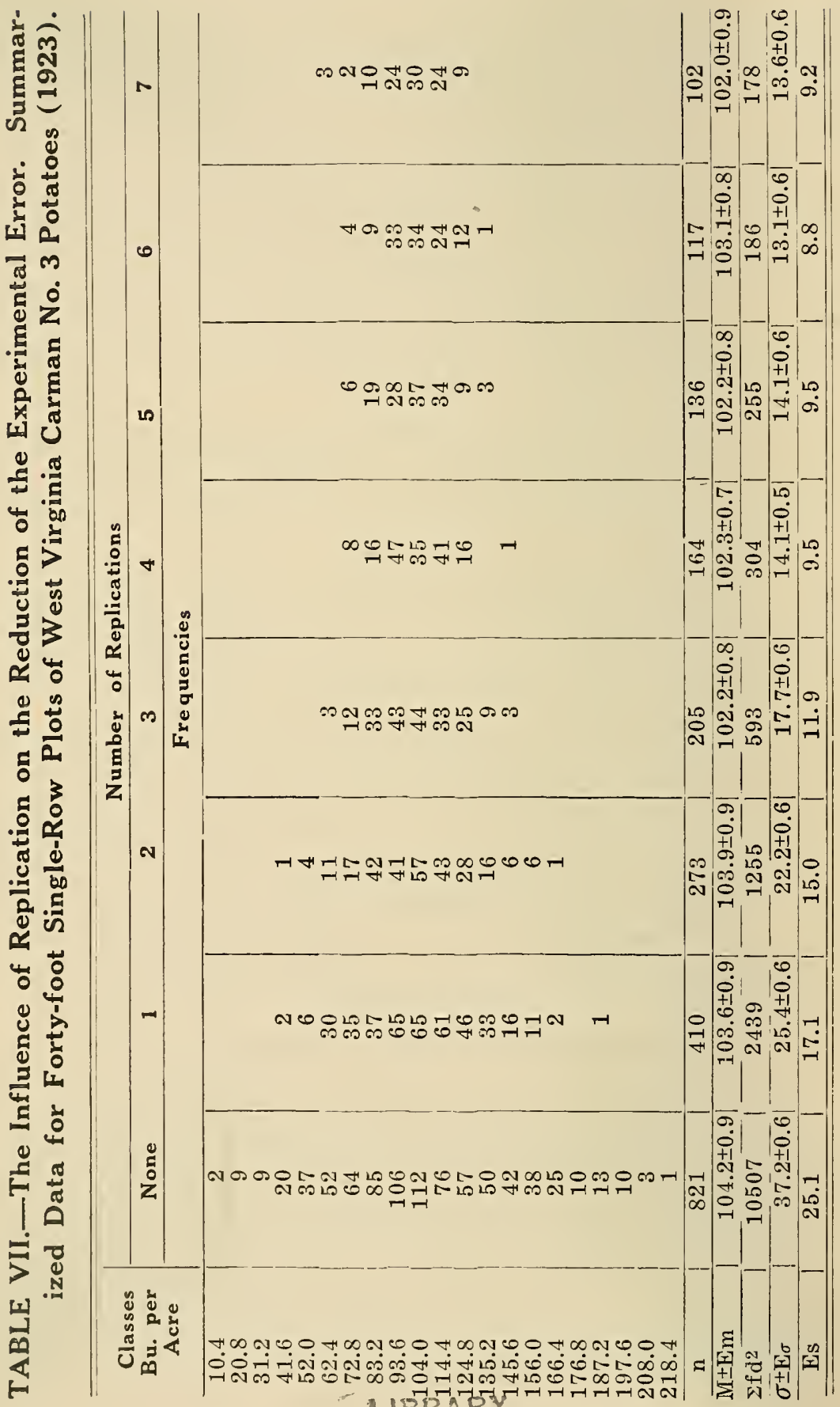


There was a reduction in probable error of 16.7 bushels per acre between the yields of the single plots and the average of the yields of eight distributed plots. Fifty per cent of this reduction occurred with the average of the yields of two distributed plots, sixty-four per cent with the average of the yields of three distributed plots, eighty-three per cent with the average of the yields of four distributed plots, and ninety-one per cent occurred with the average of the yields of five distributed plots.

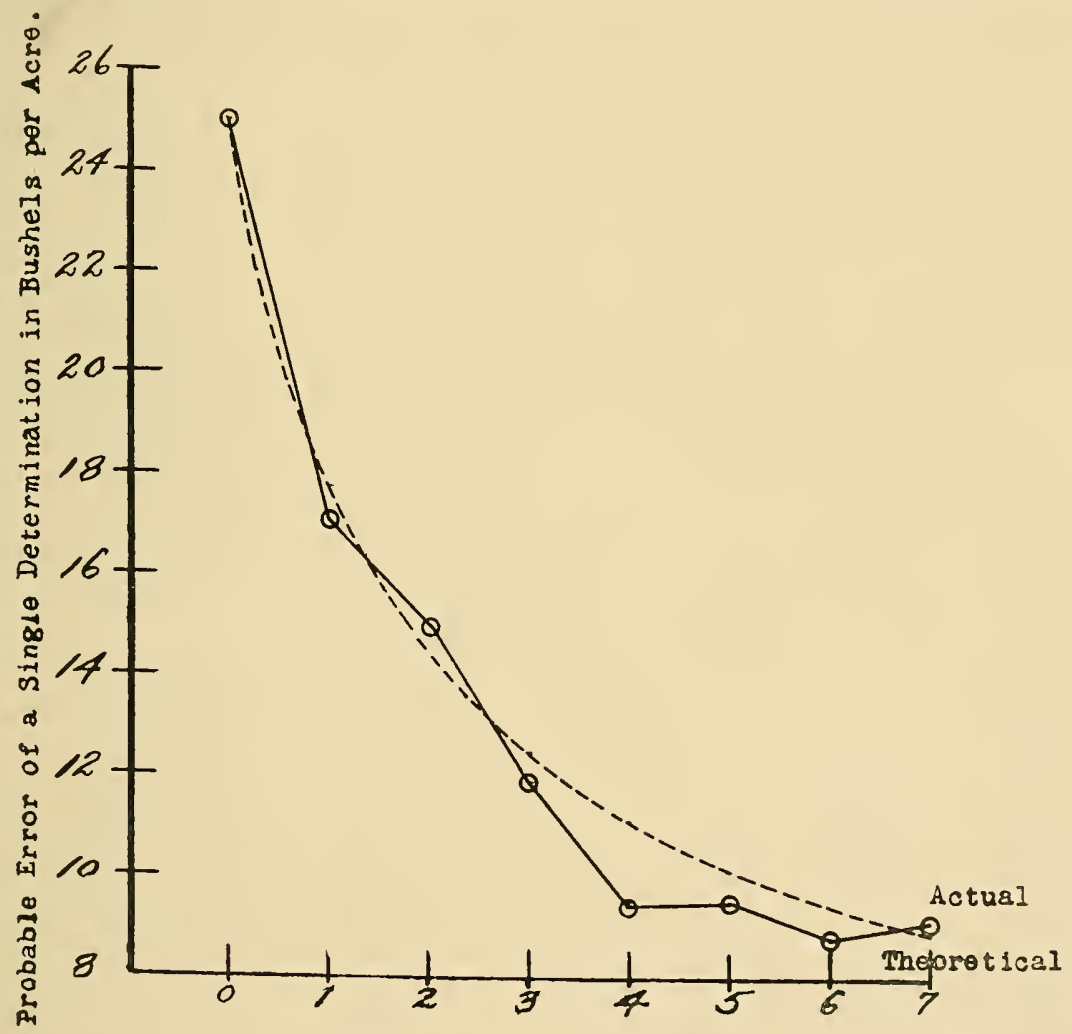

Number of Replications.

Fig. 9. The Curves of the Actual and the Theoretical Probable Errors for Varying Numbers of Replications of Forty-foot Single-row Plots of West Virginia Carman No. 3 Potatoes Grown in 1923.

The curves of the actual and the theoretical probable errors are given in Figure 9. They coincide very closely. The comparison of the standard deviations between the replications under consideration show the differences, as shown in Figure 11 (g), were significant between the yields of the single plots and 
the average of the yields of two distributed plots; between the average of the yields of two distributed plots and that of three distributed plots; between the average of the yields of three distributed plots and that of four distributed plots; and between the average of the yields of four distributed plots and that of five distributed plots. Beyond four replications no significant differences were found.

It would seem from the results of this analysis that sufficient accuracy may be expected from the use of a forty-foot single-row plot replicated four times.

In the second analysis of the 1923 data corresponding forty-foot lengths of a hundred and fifty-font single-row plots are used. The yields of the systematically distributed plots are averaged here as in the preceeding analysis to form the populations of the different frequency distributions considered.

TABLE VIII.-The Influence of Replication on the Reduction of the Experimental Error. Summarized Data for Corresponding Forty-foot Lengths of a Hundred and Fiftyfoot Single-Row Plots of West Virginia Carman No. 3 Potatoes (1923).

\begin{tabular}{|c|c|c|c|c|c|c|}
\hline \multirow{3}{*}{$\begin{array}{c}\text { Classes } \\
\text { Bu. per } \\
\text { Acre }\end{array}$} & \multicolumn{6}{|c|}{ Number of Replications } \\
\hline & None & 1 & 2 & 3 & 4 & 5 \\
\hline & \multicolumn{6}{|c|}{ Frequencies } \\
\hline $\begin{array}{r}20.8 \\
31.2 \\
41.6 \\
52.0 \\
62.4 \\
72.8 \\
83.2 \\
93.6 \\
104.0 \\
114.4 \\
124.8 \\
135.2 \\
145.6 \\
156.0 \\
166.4 \\
176.8 \\
187.2 \\
197.6 \\
208.0 \\
218.4 \\
\end{array}$ & $\begin{array}{r}2 \\
2 \\
4 \\
14 \\
12 \\
24 \\
24 \\
24 \\
21 \\
17 \\
11 \\
19 \\
20 \\
8 \\
10 \\
3 \\
3 \\
1 \\
\\
1 \\
\end{array}$ & $\begin{array}{r}5 \\
6 \\
11 \\
6 \\
18 \\
17 \\
15 \\
14 \\
9 \\
4 \\
4\end{array}$ & $\begin{array}{r}1 \\
6 \\
7 \\
15 \\
14 \\
10 \\
10 \\
5 \\
3 \\
1\end{array}$ & $\begin{array}{r}7 \\
3 \\
15 \\
8 \\
6 \\
13 \\
2 \\
1\end{array}$ & $\begin{array}{r}1 \\
3 \\
9 \\
15 \\
13 \\
3\end{array}$ & $\begin{array}{r}1 \\
1 \\
7 \\
14 \\
7 \\
5 \\
1\end{array}$ \\
\hline $\mathrm{n}$ & 220 & 110 & 73 & 55 & 44 & 36 \\
\hline$\overline{\mathrm{M}} \pm \mathrm{Em}$ & $105.2 \pm 1.7$ & $104.2 \pm 1.7$ & $105.6 \pm 1.8$ & $104.0 \pm 1.7$ & $104.0 \pm 1.2$ & $106.3 \pm 1.4$ \\
\hline$\Sigma f d^{2}$ & 2901 & 741 & 354 & 182 & \begin{tabular}{|l|}
55 \\
\end{tabular} & 56 \\
\hline$\sigma \pm \mathrm{E} \sigma$ & $37.7 \pm 1.2$ & $27.0 \pm 1.2$ & $22.8 \pm 1.3$ & $18.9 \pm 1.2$ & $11.6 \pm 0.8$ & $12.8 \pm 1.0$ \\
\hline Es & 25.5 & 18.2 & 15.4 & 12.8 & 7.8 & 8.6 \\
\hline
\end{tabular}


The summary of this analysis is given in Table VII. Because of the greater distances between the distributed plots in this analysis the populations ranged in number from 220 in the frequency distribution for the yields of the single plots to 36 in the frequency distribution for the average of the yields of six similar plots systematically distributed (five replications).

The reduction in probable error between the yields of the single plots and the average of the yields of the six distributed plots was 16.9 bushels per acre. Forty-three per cent of this re-

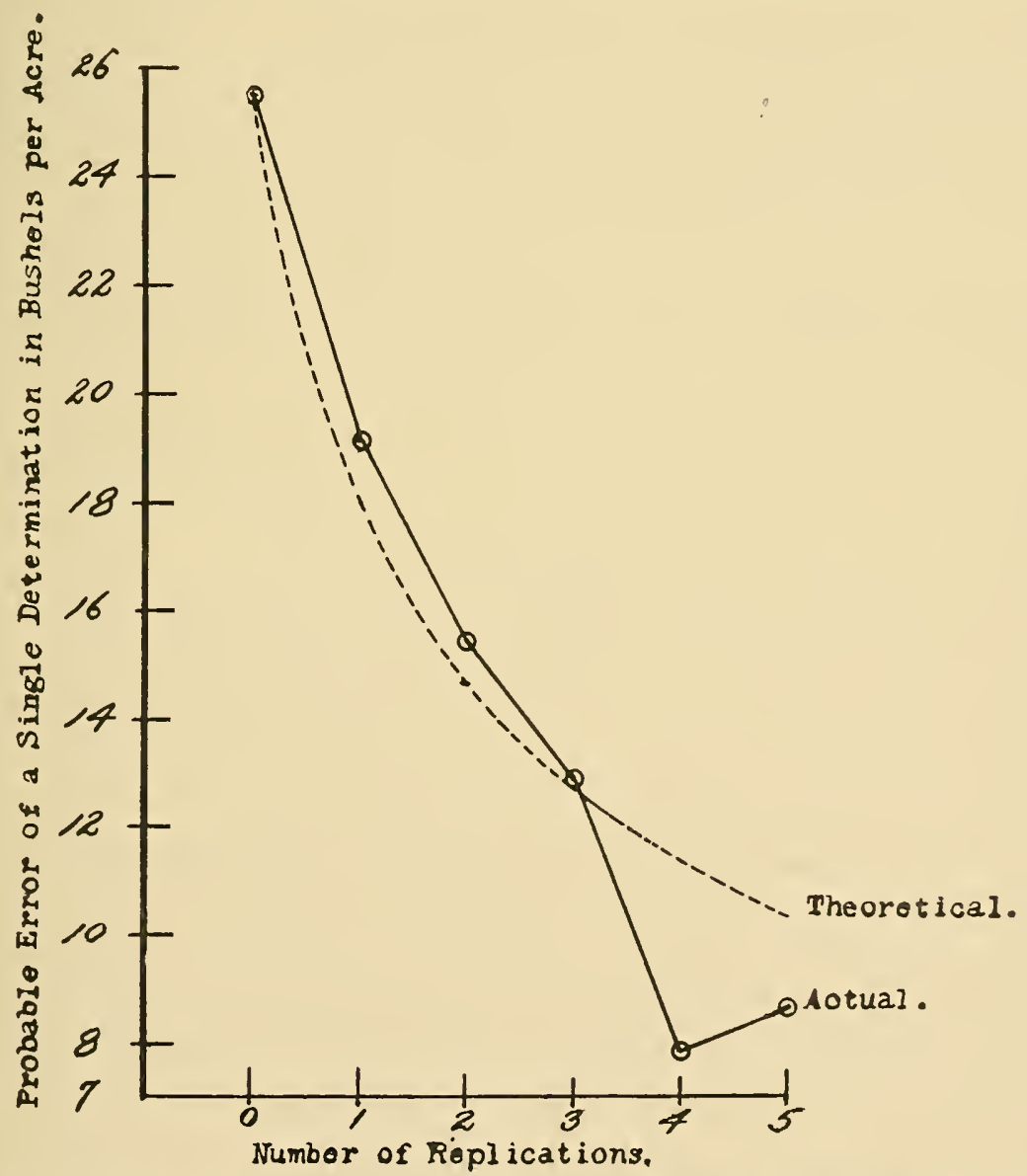

Fig. 10. - The Curves of the Actual and the Theoretical Probable Errors for Varying Numbers of Replications of Corresponding Forty-foot Lengths of the Hundred and Fifty-foot Single-row Plots of West Virginia Carman No. 3 Potatoes Grown in 1923. 
duction occurred between the yields of the single plots and the average of the yields of two distributed plots and seventy-five per cent between the average of the yield of two distributed plots and that of four distributed plots. Due probably to chance the probable error of the average of the yields of five distributed plots is less than that of the average of the yields of six distributed plots.

The curves of the actual and the theoretical probable errors in Figure 10 are very similar. Significant differences in standard deviation between the varying numbers of replications, as shown in Figure $11(\mathrm{~h})$, were found between the yields of the single plots and the average of the yields of two distributed plots, between the average of the yields of two plots and that of four distributed plots, and between the average of the yields of four plots and that of five distributed plots.

The foregoing analysis indicates that trustworthy results may be expected from the use of a forty-foot single-row plot replicated four times. 


\section{DISCUSSION AND CONCLUSIONS}

In studies of this sort it is usually the endeavor of the investigators to choose level areas with soils which are uniformly fertile, or which have the increase or decrease in fertility occurring gradually in one direction, in order that the plots may be laid out in such a way as to minimize the experimental error. In this section of West Virginia it is difficult to approach conditions ideal for experimental purposes. The areas selected for these studies were purposely chosen because they were representative of the soils over the greater part of the state and at the same time they were the best sites available.

The choice of area used for the 1922 planting might seem to be questionable since it had been devoted to fertilizer tests a few years before the present investigation was begun. Cover crops had been uniformly grown over the area up to the time of starting these studies. The writer saw a rye cover crop growing on the area two years after the fertilizer tests were completed and was unable to observe any abrupt differences in growth which would indicate plot boundaries; but on the contrary, the irregularities in growth were gradual and seemed to be consistent with changes in topography. Also, at harvest time, no marked increase or decrease in yields of potatoes could be observed other than would naturally be expected. A comparison of the standard deviation for a given plot size in the 1922 studies with that of the same plot size in the 1923 study shows a close similarity. The soil differences in the area used for the 1923 planting are natural since, to the writer's knowledge, it has never been used for experiments which would tend to change it in this respect. Figure 2 substantiates this statement. The results derived from the data of both years check very closely. It is not claimed that the treatment of the former fertilizer test plots in the planted area of 1922 had no influence on the variability of the soil, but rather that the differences which were due to natural conditions greatly outweighed these which may have been caused by the former plot treatments.

Attention is directed to the fact that no attempt has been made to account for "stand" except in so far as good seed and uniform planting are concerned. It was intended that the con- 
ditions prevailing during this study be as nearly representative of field conditions as possible.

The 1923 study was intended to serve as a check on the studies of 1922 in so far as plot size is concerned. The studies of both years show that, under existing conditions, the increased accuracy which might be secured by the use of a single-row potato plot of more than forty feet in length would not offset the added inconveniences involved.

It is also interesting to note that plantings of native strains only gave significant differences in standard deviation between the ten- and the twenty-foot plots. Strains from other sources required greater plot lengths to obtain significent differences.

These studies substantiate the conclusions drawn from more or less similar work with other crops; i. e. that there is a limit in plot size and number of replications beyond which no practical reduction in experimental error occurs.

Acknowledgements: The writer is greatly indebted to R. J. Garber, of the West Virginia Agricultural Experiment Station for his guidance and helpful criticisms in the attack of this problem and to T. M. Currence of the West Vrginia Agricultural Experiment Station, for his aid in the taking of data and the checking of computations.

\section{SUMMARY OF RESULTS}

A search of the literature pertaining to field technic as applied to the potato disclosed the fact that almost no information was available on this subject. Numerous papers have been published concerning very similar studies with fruits and field crops.

This investigation indicates that reliable results in field experiments with the Carman No. 3 potato under West Virginia conditions planted ten to twelve inches in the row and the rows spaced three and a half feet apart, may be expected from the use of a forty-foot single-row plot replicated four times. 


\section{LITERATURE CITED}

(1) WOOD, T. B., and STRATTON, F. J., The Interpretation of Experimental Results. Jour. Agr. Sci. $3: 417-440$ (1910).

(2) MERCER, W. B., and HALL, A. D., The Experimental Error of Field Trials. Jour. Agr. Sci. 4:107-132 (1911).

(3) MITSCHERLICH, A. E., Feldversuche mit Kartoffeln (Potato Field Trials). Landw-Jahrb. 54:703-745 (1919).

(4) CHITTENDEN, F. J., The Effect of "Place" on Yields of Crops. Jour. Roy. Hort. Soc. 44:72-74 (1919).

(5) WILSON, J., and CHITTENDEN, F. J., Some Further Experiments with Potatoes. Jour. Roy. Hort. Soc. $44: 83-88$ (1919).

(6) STEWART, F. C., Missing Hills in Potato Fields; Their Effect Upon the Yield. Agr. Exp. Sta. (Geneva) Bul. 459 (1919).

(7) STEWART, F. C., Further Studies on the Effect of Missing Hills in Potato Fields and on the Variation in the Yield of Potato Plants from Halves of the Same Tuber. Agr. Exp. Sta. (Geneva) Bul. 489 (1921).

(8) STEWART, F. C., Potato Seed Experiments-Whole Small Tubers versus Pieces of Large Tubers of the Same Plant. Agr. Exp. Sta. (Geneva) Bul. 491 (1922).

(9) FITCH, C. L., and BENNETT, E. R., The Potato Industry of Colorado. Colorado Agr. Exp. Sta. Bul. 175:65-68 (1910).

(10) BROWN, A. B., Plot Competition with Potatoes. Jour. Am. Soc. Agron. 14:257-258 (1922).

(11) MEYERS, C. H., and PERRY, F. R., Analysis and Interpretation of Data Obtained in Comparative Tests of Potatoes. Jour. Am. Soc. Agron. 15:239-253 (1923). 




\section{HECKMAN}

BINDERY INC.

\section{JUNE 99}

N MANCHESTER INDIANA 46962 
